\title{
The dynamics of toxic dust in Senegal
}

\section{Introduction: La poussière (dust)}

In the railway depot of the Petit Train de Banlieue (PTB), in the town of Rufisque, the railway workers Abdoulaye, Moussa and Ibrahima ${ }^{1}$ are all crammed in the cab of an old locomotive. Moussa's upper body has nearly disappeared into the machine's belly, his stretched-out arms speckled with grease and oil stains are carefully manoeuvring the organs of the cab. With Ibrahima, he is working on replacing the brakes of a locomotive of the PTB. While both of them have been working at the PTB for 7 years, Abdoulaye, an engineer specialised in bogie frames, has 25 years of railway experience. He is watching them and handing over some tools. The PTB connects Dakar to its suburbs, including the town of Rufisque - where the main train depot of the PTB is located - and the city of Thiès, where you can find semi-abandoned workshops of the old Dakar-Bamako railway. The PTB started as a service of the Senegalese national railway company, under the name Little Blue Train in 1987, before it was renamed Little Suburban Train and became a public limited company owned by the state in 2003 when the Dakar-Bamako line was privatised. Tapping on the board of the engine, Abdoulaye explains the origin of the locomotive we are in:

She's from India, and is not new anymore. You know, they send us machines, but they don't give us spare parts. That's our problem. Now we workers are left to fend for ourselves and suffer a lot with these dysfunctional machines. We've been trying but you know, the machines are running. Something that runs gets used and needs maintenance...

His explanations are interrupted by the throbbing and roaring of the engine as the two others check whether their reparations are effective. Dust whirls up, and Moussa, the thermal engineer, swiftly lifts his body out of the machine coughing. 'La poussière est partout' (dust is everywhere), Moussa shouts over the noise as he covers his mouth with his t-shirt. It is November, a few days before the pilgrimage of the Gamou (Maouloud), and the railway men have to be particularly careful and well-prepared to ensure the safe transport of the pilgrims who will make their way to Tivaouane where they celebrate the birth of the prophet Mohammed. On top of the daily repair practices, the seats have to be dusted and some coaches repainted, for this event. Not only the dusting will enrobe the workers in a fine haze in the next days and weeks, but also the spray-painting with aerosols. Dust, sand and pollution are elements that accompany the railway men, and other residents in Dakar and Rufisque, on a daily basis. However, the mix of dusty substances commonly subsumed under and referred to as 'poussière' by the residents also consists of another material for the railway men: As with the coaches imported from France in the

\footnotetext{
${ }^{1}$ All names are pseudonyms.
} 
$20^{\text {th }}$ century, the current ones from India also contain insulating asbestos fibres. These are slowly crumbling with the workers' daily reparations releasing a toxic mix of substances in the air, unseen but felt in the lungs.
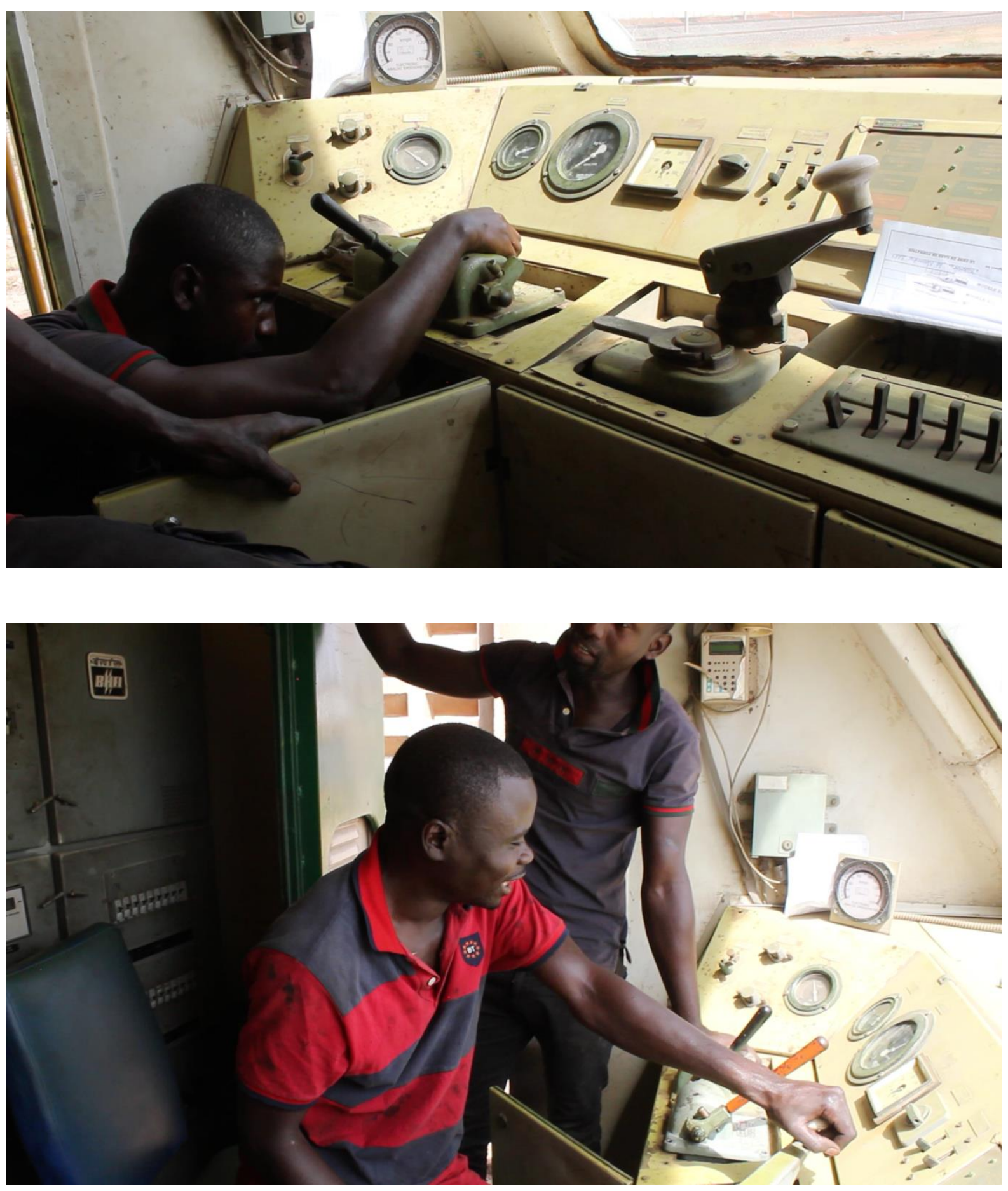

Fig. 1 and 2. Repair works in the depot of Rufisque ${ }^{2}$

Yet the railway workers' attempts to repair are particularly important at the moment, as they need to show that they are capable of making the PTB run. Any dysfunction will be a further argument for the

${ }^{2}$ All pictures my own. 
Senegalese government to suspend the PTB's services, as the railway men explain. They fear that the new Regional Express Train (TER) whose tracks are being built next to the PTB's will soon replace the latter. The TER construction sites have already considerable reduced the PTB's services, leaving the railway men with less customers and fewer working hours. While they initially thought that they would be redeployed at the TER, their hope is slowly dwindling as the state keeps evading the PTB labour union's question about their future. They might end like many of their relatives working for the DakarBamako railway that used to run on the same tracks as the PTB and continued till Bamako: The failure of its privatisation and of the ensuing transitory railway operator Dakar-Bamako Ferrovaire (DBF) has left the DBF railway workers waiting for their train to restart since 2018. What would become of the PTB railway men's and their families' future if they lost their jobs?

This piece is based on twelve months of ethnographic fieldwork amongst DBF and PTB railway workers in rail yards and stations across Senegal and Mali. It specifically homes in on the PTB rail depot in the town of Rufisque, east of Dakar. Part one focuses on the repair practices and narratives of the PTB workers to show how asbestos is entangled in the histories of the dusty coaches. In the second part, by examining how the rail workers in Senegal express their daily, intimate encounters with the fine, dry and often invisible substance that provokes physical degradation and daily aches, the dust becomes an archive of labour whose layered sediments pull simultaneously in different directions: past, present and future. Dust emerges as a compelling material and metaphor here, not only as a trace of the past that feeds into a toxic present but also one that points to an uncertain future. Indeed, the railway workers are desperately trying to keep the carriages and lines going by constantly repairing them to extend the lifelines of the railway, and thus of their jobs. By disentangling the nostalgic, future and toxic aspects woven into the railway, the attention to dust helps materialise how an otherwise invisible toxicant travels across geographies and leaves durable traces in the organisms of men and machines.

In this vein, the paper joins studies inspired by Ann Stoler's work on imperial debris that has looked at the engagement of humans with remains of infrastructure, ruins, waste and rubble to highlight the traces of colonial aftermaths. Some of this work has focused on the toxic leftovers with which people have to cohabit in their everyday lives, thus contributing to a broader project that explores waste coloniality and toxicity in Africa (Chari 2013, Gupta and Hecht 2017, Hoffman 2017). My aim is to put these in relation with more 'geo-social' studies focusing on the granular materiality of substances to reflect on the encounter between humans and mineral materials such as sand (Nigel Clark and Kathryn Yusoff 2017) or in my case dust. This enables me to think through the physical and affective implications that the railway workers' encounter with the dust contained in the trains and depots engender: Physical, in the sense that the focus on dust sheds light on the porosity and permeability of the body (Clarke 2019, Litvintseva 2019, Nieuwenhuis 2019) and affective, in the ways in which narratives around the dust transcend the phenomenological sensations of the body to encompass also feelings of nostalgia or of 
anxieties that the railway infrastructures and the memories attached to them evoke cutting across time and space (Bear 2007, Finkelstein 2019, Nassar 2018).

\section{Traveling asbestos}

Abdoulaye often sits down with me to talk about the different trains types have been part of the PTB fleet and that he or his father, a former DBF station master, have worked with. He can enumerate most of them: from the early French trains, the General Motors fleet, and the stainless, rebuilt Mistral cars, once the world's fastest train operating between Paris and Marseilles in 1950, to the Pakistani and Indian ones. The Wolof term for trains is "Saxaar" meaning smoke and comes from the first steam locomotives imported from France at the end of the $19^{\text {th }}$ century, Abdoulaye tells me. 'Smoke and dust accompanied us already back then,' he laughs. In honour of the Senegalese and Malian railway workers' strike in 1947, they recently named one of their trains after the Senegalese resistance hero Lat Dior who fought against French incursions into the Cayor territory in the $19^{\text {th }}$ century. When remembering the histories of trains, other memories of more productive, postcolonial pasts where railway workers enjoyed a higher status in West Africa emerge. While some of the memories were passed on to him by the previous generation of railway workers, he too remembers busy railway stations and the constant sound of the machines in the depot.

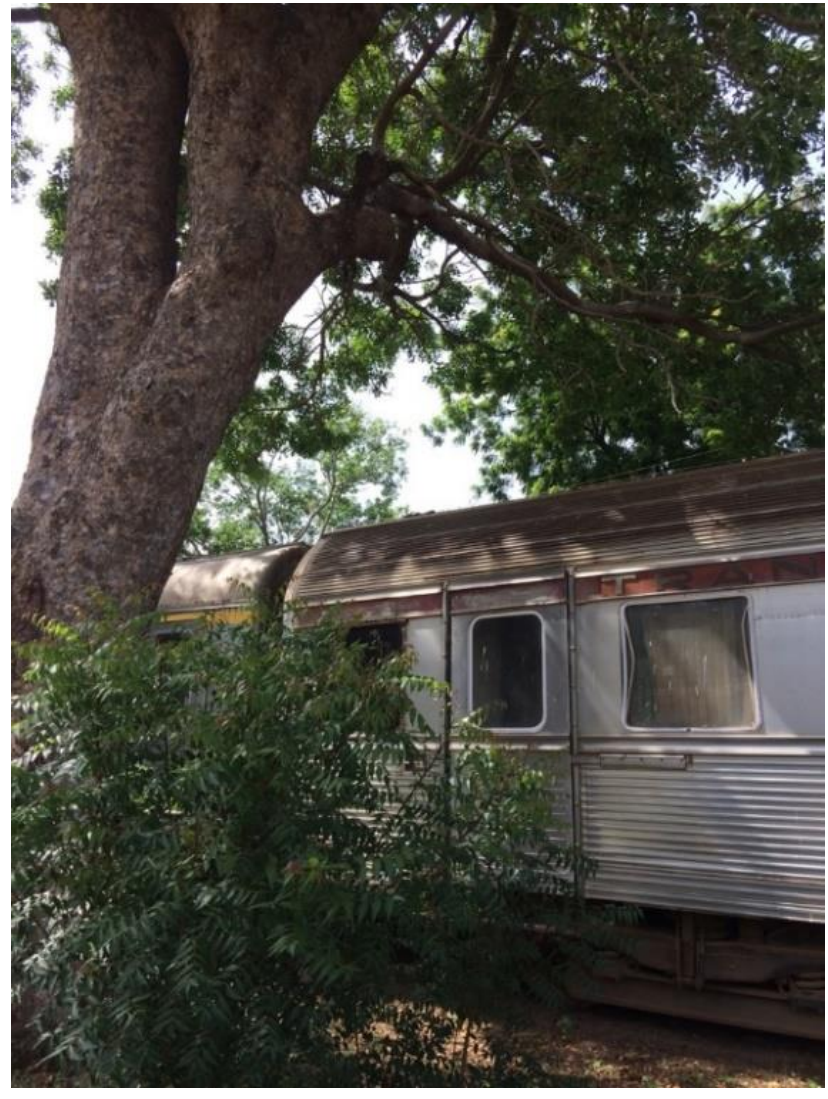

Fig. 3 Former Trans-Europe Express coaches from the SNCF outside the railway workshop in Thiès

These affective recollections shine through when the railway workers show me the dust-covered coaches that previously transported high-ranking officials during international presidential visits and are now part of the nearly abandoned landscape of the DBF workshop in Thiès. This excitement and past pride, alongside anxieties concerning the railway workers' future, become palpable during this year's preparation of the Gamou pilgrimage to Tivaouane. By being able to fulfil such an important social and religious function, they felt useful again, Moussa explained with a smile. Taking the pilgrimage train with them, I could sense the delight that they uttered at the sound and sight of the passengers, the hustle bustle of street vendors who animated the train 
stations, the children running next to the coaches when departing and even at the police officers who made sure that nobody was infringing the rules.

Yet, the memories that they evoke when talking about the past of the coaches also contain more dangerous, toxic legacies that the railway men reveal as I probe further into the origin of the materials. On one of our strolls through ranges of old and empty coaches stationed outside the depot, Abdoulaye shows me with pride the wooden interior of the Restaurant Car of an Indian coach that has not been used for some time now. The coach is waiting here as the railway men renovate it alongside their normal shifts when they have time. A silver plaque indicates that these coaches were refurbished at the Rail Coach Factory (RCF) in Kapurthala in India in 2006 and delivered to Senegal one year later. As Abdoulaye tells me, they were acquired under President Abdoulaye Wade's spirit of South-South cooperation. In that context, small groups of Senegalese and Malian railway workers, including the mechanical engineer Ibrahima, were sent to railway establishments across India completing 2 monthlong trainings on the maintenance of the imported coaches. Abdoulaye takes a towel to wipe over the light brown wooden bar. He explains the changes they are making and gestures to the gangway

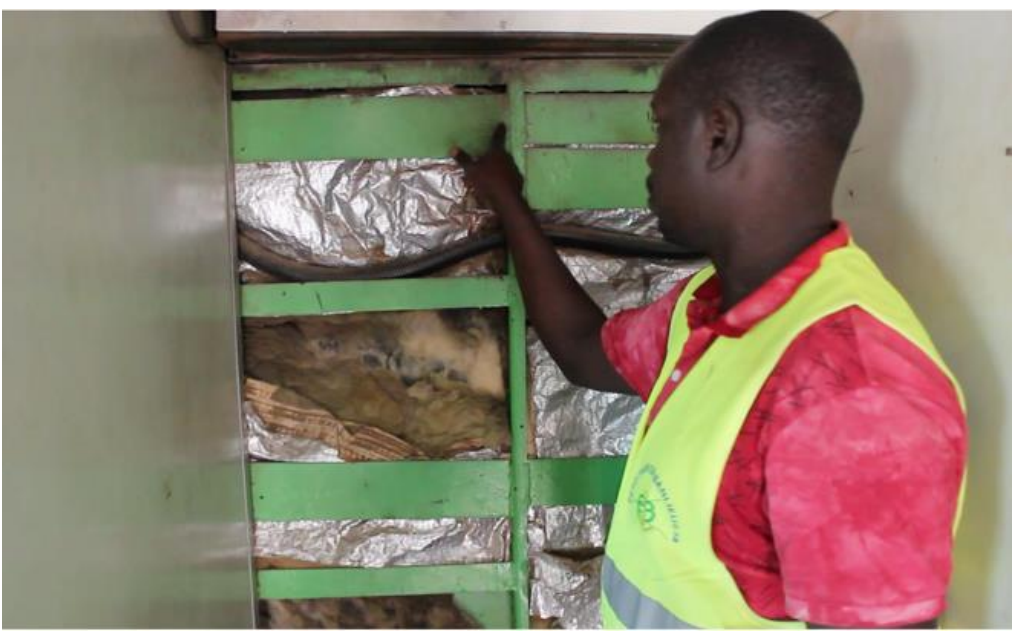

Fig. 4 Abdoulaye explaining the insulation system of a train connection where part of the train wall has been torn down, laying bare white and aluminium-looking bits and pieces: 'They say asbestos dust is dangerous when exposed. But if left untouched, it is safe. It contains heat and prevents it from getting inside the car. Without it, the heat would kill the customers, the insulation would be meaningless'.

As flexible fibres that are resistant to heat, electricity and corrosion, asbestos has indeed been used over the years across the world for the construction and insulation of roofs, wall cladding, floor tiles, pipes and other materials that include cement, plastic, paper or cloth. However, the mineral becomes hazardous when it crumbles, is damaged or in need of repair, and the released dust is inhaled. Although medical journals already warned of asbestos' toxic effects on health such as lung cancers, asbestosis and mesothelioma in the late $19^{\text {th }}$ century, it took several decades until the first regulations were put in place. While an EU-wide ban took effect in 2005, other countries have been lagging behind (such as Canada where it was only banned in 2018). It continues to be mined in Russia, Kazakhstan and China and exported to countries like India which is the world's largest importer in asbestos (Zandwijk et al. 2020). Despite the increase in regulations, the enforcement remains patchy across the world as the low 
cost of asbestos attracts many sectors that are 'beyond the reach of government regulators' (Sellers and Melling 2011: 2), thus revealing unequal landscapes of regulations and environmental deterioration. Moreover, even countries that have banned it still have to deal with traces and legacies of asbestos that remain in buildings and structures (Gregson et al. 2010: 1066). As Abdoulaye explains, both scenarios apply to the railway depot in Rufisque: While it is true that the railway men still currently use the mineral for small repair works such as electric conduits, its presence can mainly be traced back to the origin of the machines and their transnational histories of export from India and France.

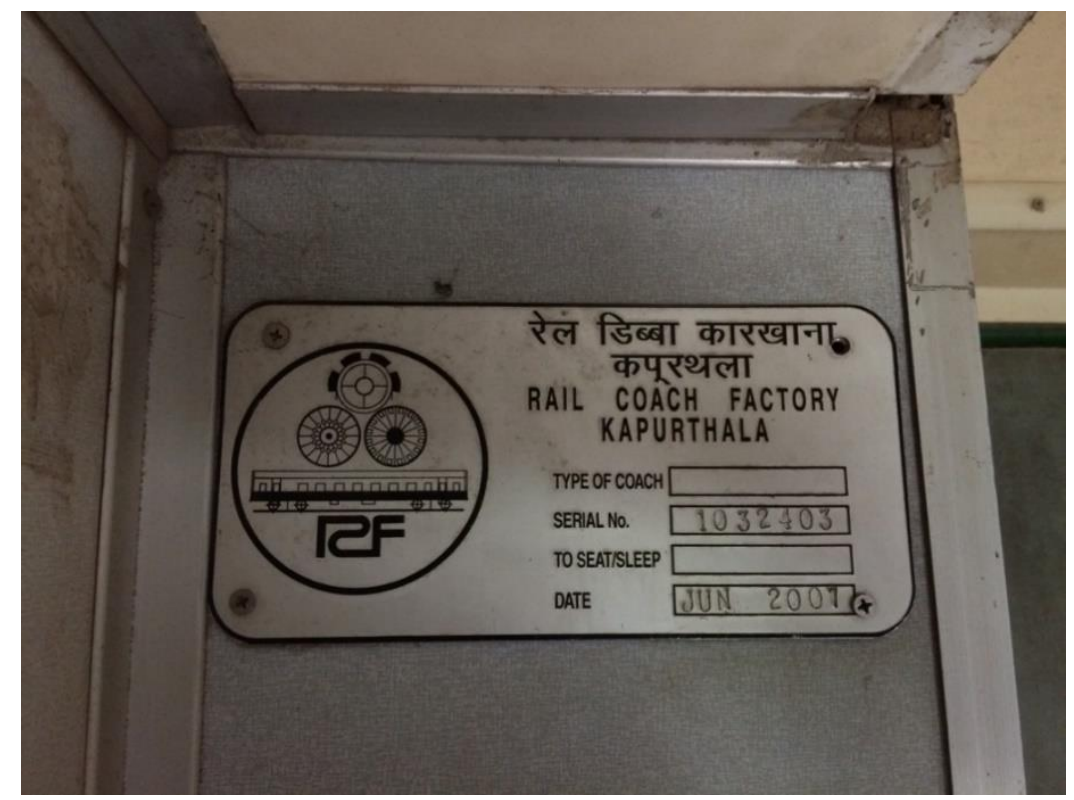

Fig. 5 Plaque of the Rail Coach Factory Kapurthala on board of a passenger coach

\section{Of machines and men}

Aware of the danger involved in being exposed to the mineral, Abdoulaye who is already a senior worker, is worried that the repair and dusting make the asbestos crumble. As we continue our discussion, anxiety creeps into his stories as the body takes precedence:

A lot of people get sick because of the way they work. Before you start working, you actually have to prepare and apply safety provisions. I'm not letting myself be forced to do anything that can harm my health. I asked for the necessary material so that at least we could protect our skin and eyes and breathe safely. But since the administration didn't respond to this, I don't want to expose myself either. If the younger workers want to take this risk, let them do it. I'll complete other tasks.

Most of Abdoulaye's fellow workers have heard about the toxicity of asbestos, 'that it is dangerous when the particles are released' as Abdoulaye repeated a few times but at the same time he is also confronted with his colleagues' mocking comments questioning his manliness when refusing to 
participate in certain activities. Indeed, different ideals of masculinity play into these discussions, about being able to "stand up to the boss" as Abdoulaye put it and being 'too weak' to perform the hard work as his co-workers provoked him. Behind those quarrels about manhood, the danger surrounding asbestos is downplayed as not being a priority, or considered a luxury compared to more practical concerns about the present. As the head of the labour union, Ousmane, later explains 'we don't have the time to worry about this'. For him, asking someone to test for asbestos would cost a lot of money that they don't have. It would also distract from their main concerns which are, he explains, to make the trains work as best as they can to ensure an income.
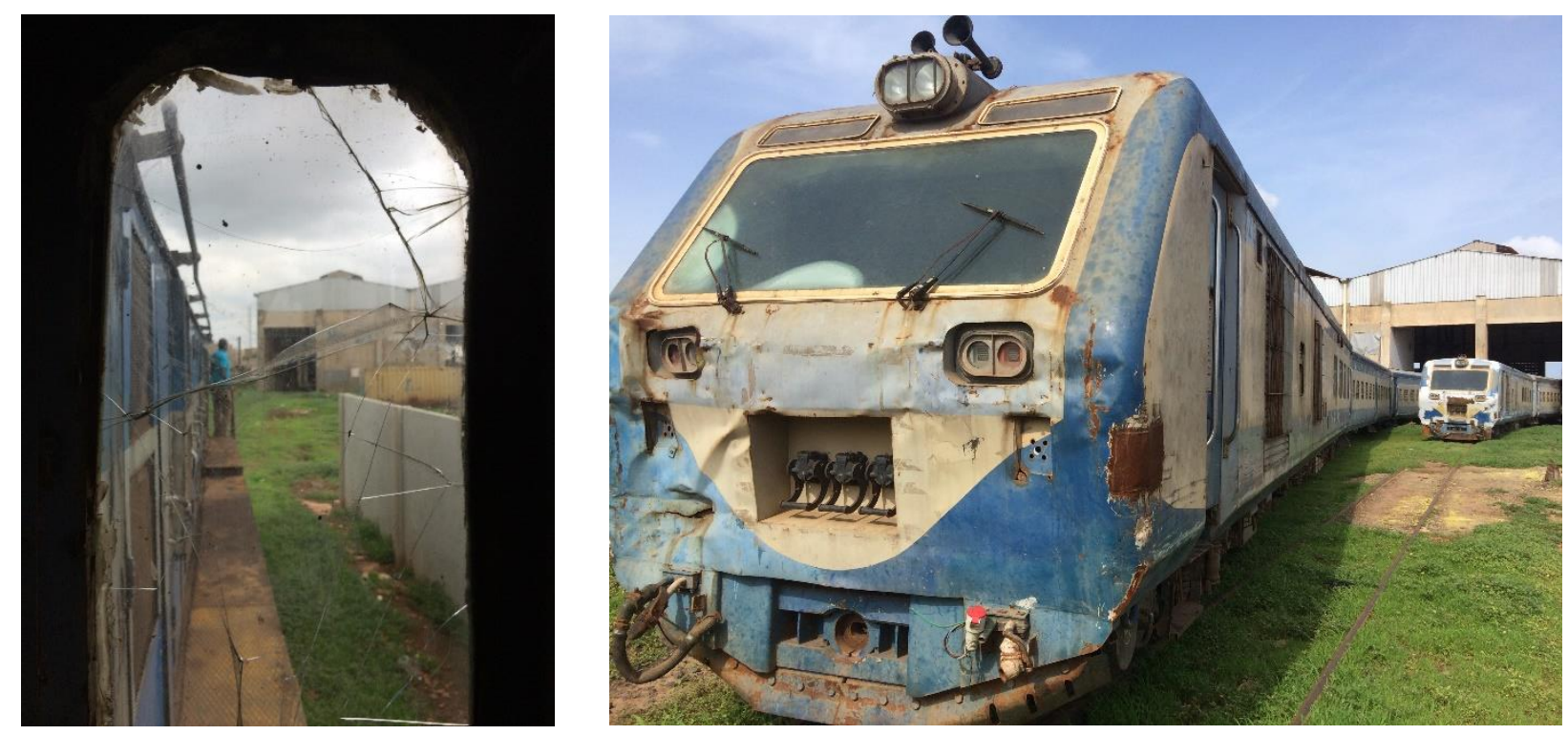

Fig. 6 and 7 Inside and outside the trains at the depot in Rufisque

And yet, although many of the railway workers renovate and paint the coaches with great fervour to demonstrate the workers' and machines' capacity to continue the PTB services despite the new TER's arrival, Abdoulaye is not the only one to be wary. Most of the railway men dismiss the painting as trivial compared to the major reparation issues that are more important to avoid accidents: 'Wear and tear is unforgivable. Train organs are like people's organs, you have to take care of them. The colour is beautiful but it is superficial. It's just a way to keep us occupied while they are actually planning the end of the PTB.' Others deem it unsafe considering the lack of adequate gear that would protect them from the dust released when sanding damaged surfaces and applying plaster to fill cracks and gaps in the trains. Few wear masks and no one has appropriate protection glasses. 'Surely, in your countries, one does it differently' calls Moussa out of the locomotive. 'But our bodies are not less worthy than yours, are they?' he laughs, his teasing tone however echoing sadly in the depot as he connects his body and mine to global inequalities. 


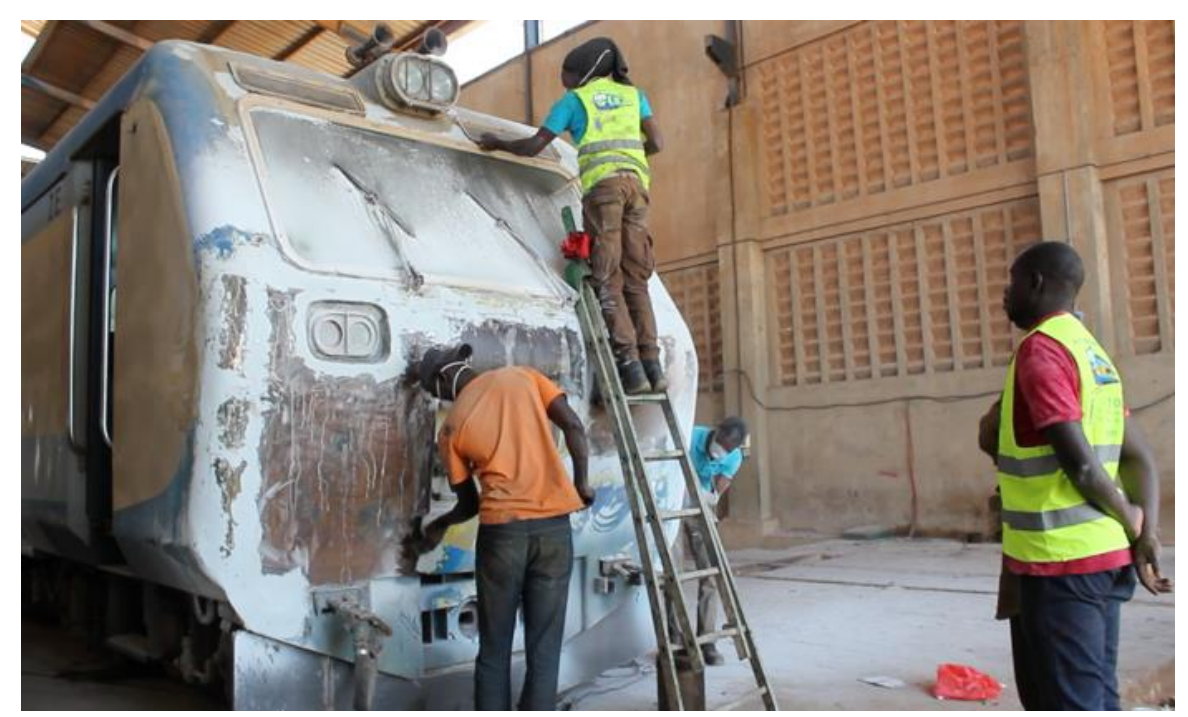

Fig 8. Workers sanding a locomotive before applying paint in the depot of Rufisque

With these words, Moussa positions himself not only in relation to me, a European researcher, but also globally, highlighting the racial geographies that underlie the offshoring of toxicity to "developing" countries such as the one of waste dumped in the "Global South" (Margai and Barry 2011). In recounting the history of the coaches from India and the used French trains that Senegal received at a time when the asbestos ban had not yet been introduced in France, he adds another historical layer to the trajectory of these toxic debris making the accumulated dust a trace of an imperial present (Stoler 2008: 204-205).

Here, the dust's various layers pull into different directions: the dust does not only carry sediments of memories and the past of the coaches, but also foregrounds an already lost future that seems to slip through the rail workers' fingers like sand: indirectly, in the sense of a loss of livelihood but also directly with corporeal implications such as asbestos-related diseases that the rail workers will most likely face. Once I got to know them better, the rail men started talking about breathing and vision problems, accidents that had to be treated and were never reimbursed, demonstrating for them the industrial abandonment and negligence that they have endured over years. 'Even if we go to the hospital with symptoms, we don't know exactly what they are linked to. Most of the time, the diagnoses are quite vague.' Moussa's older colleague, a now retired train conductor, spent one year at the hospital with what was diagnosed as pneumonia, the industrial dust and debris having forged their traces onto his body. As his pension was not sufficient for the family, he had to take up smaller jobs, where he had another accident and was hospitalised again, this time for an operation. Discussions on dust amongst the railway workers become then an archive of labour that stores different forms of bodily pains and injustices (Bear 2007, Finkelstein 2019). 


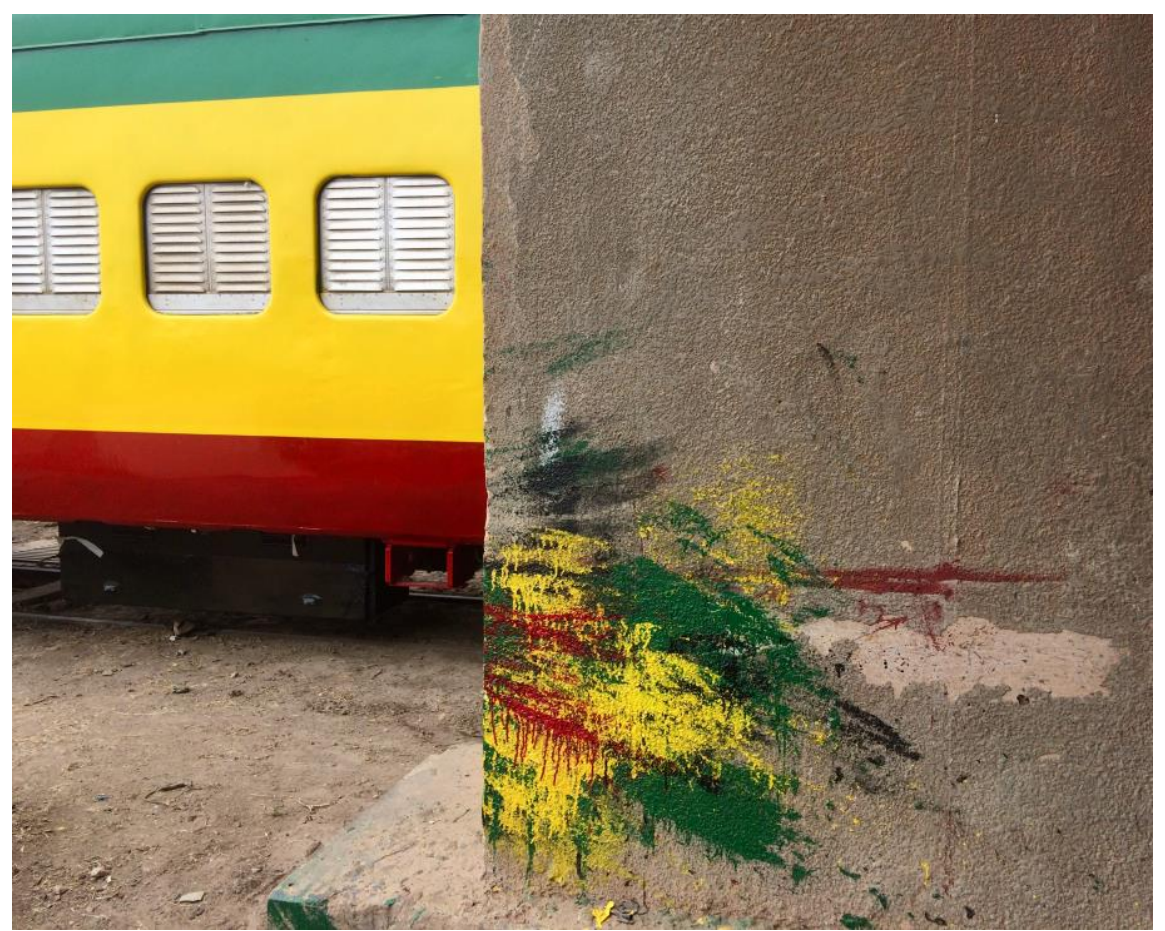

Fig. 9 The trains were repainted in the colours of the Senegalese flag

'It is also not the right time to engage in those sanding and repainting activities', Ibrahima adds, as 'there will be more dust'. Asking him what he exactly means, he explains that the Harmattan wind with its fine sand particles will soon start blowing from Mauritania mixing itself with Dakar's already significant levels of pollution. Indeed, in Dakar and its surroundings, the concentration of fine particles mostly emitted by traffic, particularly second-hand vehicles and fossil industries is on average five times higher than the WHO guidelines, ${ }^{3}$ contributing to a rise in respiratory diseases. ${ }^{4}$ The railway workers' personal breathing issues linked to their labour environment are hence submerged by the discussions about the more wide-spread dust in the media and the general population that announces the beginning of the Harmattan and with it the pollution peak.

The pervasiveness of the different layers of dust as it seeps into the bodies of the workers and machines reminds me of Aya Nassar's encounter of dust during her fieldwork in Cairo: 'Even as it [dust] appears passive, it covers, shelters and settles on surfaces, dulling them, at times corroding them, but also making them more visible' (2018: 413). Similarly, in the rail workers' stories, the pervasive nature of asbestos dust testifies to the 'viscous porosity, and reciprocal interpenetration' between the human and the fibre (Litvintseva 2019: 152). Seeping across the boundaries between bodies, machines and environment, as well as toxic and non-toxic spaces the dust joins and connects them to wider processes of globalisation and waste colonialism. While asbestos is invisible to the naked eye, its material presence as crumbling matter reveals itself by entering the organisms of machines and men with temporally unknown consequences. As the 40 -year old rail worker Ibou explains pointing to his chest:

\footnotetext{
${ }^{3}$ Matteo Maillard, "Dakar étouffe sous les particules fines", Le Monde Afrique, 3 June 2019, https://www.lemonde.fr/planete/article/2019/06/03/dakar-etouffe-sous-les-particules-fines_5470761_3244.html, accessed 1 August 2020.

${ }^{4}$ Louise Dewast, "'Our children are gasping' - Senegal's toxic air battle", BBC Africa, 9 April 2019, https://www.bbc.com/news/world-africa-47820939, accessed 15 August 2020.
} 
'At times, I have the feeling that something gets stuck deep in my lungs and it might manifest itself later on. At the moment, we're okay, but for the asthmatic ones, it's more difficult'.

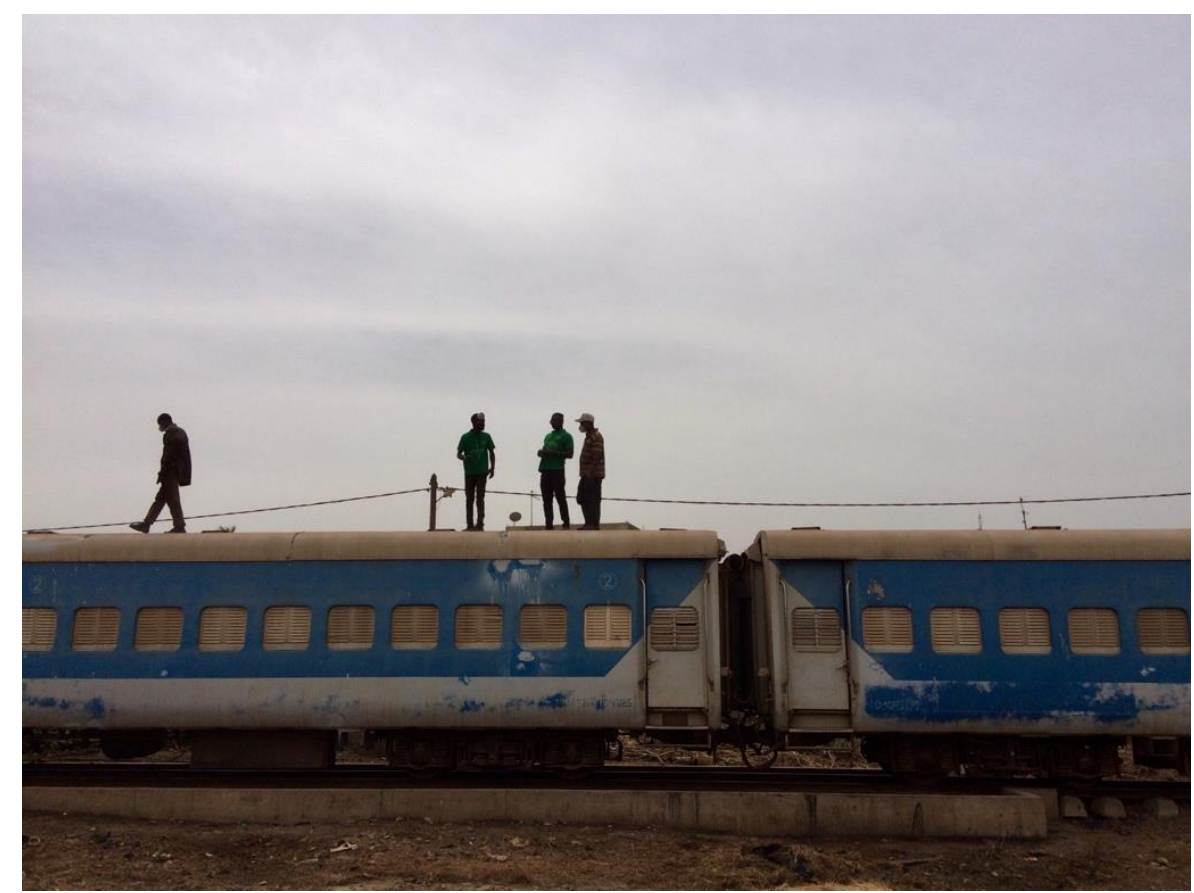

Fig 10. Railway workers on a check-up tour of the PTB coaches

To think about the dust sediments that have accumulated over time and bind the rail workers to their technologies through affective, historical memories and their need of subsistence, shows us how the workers' physical degradation goes hand in hand with the ruination of their industrial environment making both invariably part of the railway men's stories about the past and future. At the same time, ideas of masculinity and weakness also inform how the workers' handle the dust that turns them into victims of a nearly invisible substance. The bodies become then the corporeal witnesses of the workers' histories of exposure and industrial work laying bare their vulnerabilities. Indeed, although the PTB's activity has continuously decreased, with its present in suspense and its future on the verge of disappearing, the physical sensations, injuries but also expertise accumulated over the years are stowed in their bodies. Dust here, like the past, has settled as a toxic trace in the present. Wedged in between the layers of train walls and embedded under and in the rail workers' skin, it becomes at the same time a trace of an uncertain future.

\section{Conclusion}

My focus on the railway dust has shed a spatial and temporal lens on the ways in which asbestos continues to permeate the railway men's lives and bodies in a non-linear way. Carrying imprints of the past, it helps explain how the rail workers occupy and live in 'a body built and broken down through a 
lifetime of industrial labour' (Finkelstein 2019: 68). At the same time, the tensions and uncertainties that prevail in narratives about the corporeal consequences of the dust's sediments, and the ways the railway men prefer to ignore them, demonstrate how fears about the future impact their present working conditions. Despite their awareness that continuing to work in this toxic landscape in the present will have an effect on their bodies in the future, the anxiety of losing their job is often even more daunting. The aches and coughs enveloped in dust coexist with the realisation of the nearly imminent loss of a more desirable future and nostalgic memories of more productive pasts. In that sense, asbestos continues to trouble Senegalese presents, as 'a past that is not yet past' (Sharpe 2016: 13). Ultimately, paying attention to dust, in its small and nearly invisible yet granular materiality, as it emerges in the daily discourses of the workers and accompanies their practices, reveals the corporeal and affective dimension of the labour conditions of the railway workers connecting individual bodies to global inequalities at the same time as it troubles the boundaries between them. 


\section{Bibliography}

Agard-Jones, Vanessa. 2013. "Bodies in the System." Small Axe: A Caribbean Journal of Criticism, 17(3) 42, 182-192.

Bear, Laura. 2007. Lines of the Nation: Indian Railway Workers, Bureaucracy and the Intimate Historical Self. New York: Columbia University Press.

Chari, Sharad. 2013. "Detritus in Durban: Polluted Environs and the Biopolitics of Refusal." In Ann L. Stoler ed. Imperial Debris, Duke University Press.

Clark, Nigel \& Kathryn Yusoff. 2017. "Geosocial Formations and the Anthropocene." Theory, Culture \& Society 34 (2-3): 3-23.

Clarke, Jennifer. 2019. "Porosity and Protection." Theorizing the Contemporary, Fieldsights, https://culanth.org/fieldsights/porosity-and-protection.

Margai, Florence \& Barry, Fatoumata. 2011. "Global Geographies of Environmental Injustice and Health: A Case Study of Illegal Hazardous Waste Dumping in Côte d'Ivoire”. In McLafferty, Sara and Juliana Maantay eds. Geospatial Analysis of Environmental Health. Springer.

Finkelstein, Maura. 2019. The Archive of Loss: Lively Ruination in Mill Land Mumbai. Durham and London: Duke University Press.

Gupta, Pamila and Gabrielle Hecht. 2017. “Toxicity, Waste, Detritus: An Introduction.” Somatosphere. http://somatosphere.net/2017/toxicity-waste-detritus-an-introduction.html/

Gregson, Nicky, Helen Watkins \& Melania Calestani. 2010. "Inextinguishable Fibres: Demolition and the Vital Materialisms of Asbestos". Environment and Planning A: Economy and Space, 42(5), 10651083.

Hoffman, Danny. 2017. “Toxicity”. Somatosphere. http://somatosphere.net/2017/toxicity.html/.

Litvintseva, Sasha 2019. "Asbestos: Inside and Outside, Toxic and Haptic." Environmental Humanities 11(1), 152-173.

Nassar, Aya. 2018. "Where the dust settles: fieldwork, subjectivity and materiality in Cairo." Contemporary Social Science, 13(3-4), 412-428.

Nieuwenhuis, M. 2019. Porous skin: Breathing through the prism of the holey body. Emotion, Space and Society 33. Available online 16 September 2019.

Sellers, Christopher \& Melling, Joseph. 2011. "Introduction.” In Sellers, Christopher \& Melling, Joseph (eds.) Dangerous Trade: Histories of Industrial Hazard across a Globalizing World. Philadelphia: Temple University Press. 
Sharpe, Christina. 2016. In the Wake: On Blackness and Being. Durham and London: Duke University Press.

Stoler, Ann L. ed. 2013. Imperial Debris: On Ruins and Ruination. Durham: Duke University Press.

Zandwijk, Nico van, Glen Reid \& Arthur Frank (2020). “Asbestos-related cancers: the 'Hidden Killer' remains a global threat." Expert Review of Anticancer Therapy, 20:4, 271-278.

Charline Kopf is a PhD candidate in social anthropology at the University of Oslo (UiO) and the Catholic University of Leuven (KU). She is interested in the anthropology of infrastructure, trade unions and logistics, as well as security and borders. Her current research focuses on the past and future reconfigurations of the Dakar-Bamako railway line and how these have shaped local practices and perceptions of labour, space and mobility in Senegal and Mali.

Heremail is charline.kopf@sai.uio.no. 